\title{
BORBÉLY-PECZE Bors
}

\section{Egy múködő modell: a dél-koreai munka-tanulás duális rendszere}

\section{Előzmények}

Korea XX. századi történelmét lényegében meghatározta a Japánnal, Oroszországgal és Kínával való összetett viszonyrendszere. Az önálló koreai államiság (Csoszon korszak 1392-1897) végét jelentette a Japán által a Koreai Császárságra kényszerített protektorátusi szerződés (1905) majd lényegében a japán megszállás (1910-1945). A második világháború után a koreai háború (1950-1953) végére a félsziget kettéosztottá vált. Az ötvenes évek elején egy háború sújtotta, szegény ország képe rajzolódott ki. Az egy före jutó nemzeti össztermék 134 US dollár volt (Ilho, 2008). Azután az 1960-as években bekövetkezett az ország gazdasági stabilizációja és iparosítása, az 1960-as évek eleje és 1975 között az átlagos éves GDP növekedés üteme elérte a 9.1\%-ot (Ilho, 2008:35). A gyors iparosodás és növekedés azonban együtt járt a társadalmi egyenlőtlenségek növekedésével, illetve fennmaradásával is. A monetáris politika irányítására a Koreai Központi Bank a kormány szigorú felügyelete alatt múködött és a hatvanas évek közepétôl a kormány mindent megtett annak érdekében, hogy Korea exportra termeljen miközben múködő tőkét keresett az otthoni beruházásokhoz. A jegybanki kamatot mesterségesen alacsonyan tartották, amely ösztönözte a beruházásokat. A kormányzati szektor fogyasztását GDP arányosan mindig sikerült alacsonyan tartani (1955-ben 9\%, 1998-ban 25\%), amely alacsony adóztatási szinttel társult (1955-ben 6\%, 1998-ban 22,9\%) volt a GDP arányában (Ilho 2008:44). Összehasonlításul az OECD országok átlagában a béreket terhelő adó/járulék 36\% volt 2016-ban (OECD, 2017a). Az agresszív exportpolitika és a koreai won vásárlóértékének mesterséges alulértékelésével 1963 és 1973 között a koreai ipar évi 19\%-ot növekedett. A 60-as évek elején még agár országból (agrárium aránya 28,6\% volt a GDP-ben) a 70 es; 80-as évekre erősen iparosodott állam vált. Az iparosítás és export-vezérelt növekedés érdekében erős monopóliumok, gigantikus vállalatok jöttek létre, amelyek sérülékennyé tették az országot az 1997-es ázsiai pénzügyi válság idején. A ország gazdaságának fejlesztését 1962-től ötéves gazdaságfejlesztési tervekbe foglalják. Nyilvánvaló geopolitikai tény, hogy Dél-Korea gazdasági megerősödésében a kommunista Szovjetunióval és Kínával szemben az USA érdekelt volt. 1961-ben Dél-Korea éves költségvetésének még 39\%-a jött az USA-ból (Park 2017:6). A japán gazdasághoz hasonlóan kialakuló vállalati monopólium birodalom szisztéma (keiretsu) lényegében a koreai gazdasági felemelkedésének (1960-1990-es évek) és a gazdasági sebezhetőségének (1997-es válság) a záloga is volt egyben.

\section{Koreai munkaerőpiac 2017-ben}

A mai koreai munkaerőpiac az egyik leginkább ellenálló az OECD országok sorában (OECD, 2017b), a 2008-as gazdasági válság kevéssé érintette. Talán az 1990-es évek ázsiai gazdasági válságára adott korábbi kormányzati válaszok is hozzájárultak a koreai munkaerőpiac egy-másfél évtizeddel később jó teljesítményéhez. A munkanélküliség 3,5-4\% között mozog, a 15-74 évesek foglalkoztatási rátája $64,7 \%$. A szép makro adatok mellett a koreai munkaerőpiac duális maradt, a foglalkoztatottak alig 13,6\% dolgozik nagyvállalatoknál, amíg közel fele hatékonyatlan mikro-, és KKV cégeknél áll szerződésben. A 15-29 éves fiatalok között a NEET ráta 18\%-os amely az OECD átlag felett jár (OECD, 
2017b). A fiatalok foglalkoztatási rátája az egyik legalacsonyabb az OECD országok között, miközben az idősebb munkaerő (55-64) kiszorul a munkahelyekről (OECD, 2016a).

\section{Számú táblázat a koreai munkaerőpiac, foglalkoztatási és munkanélküliségi ráták}

(15-74 évesek, 2007 IV. né. - 2018. IV. né.) OECD, 2017

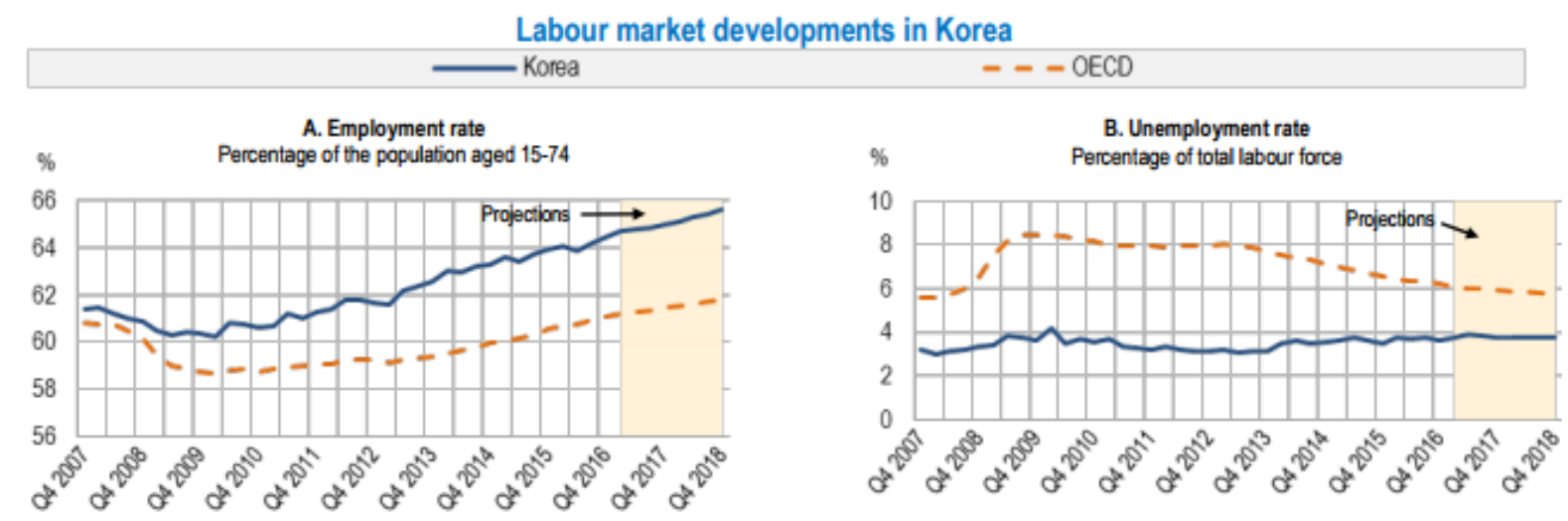

Note: $\mathrm{OECD}$ weighted average.

Source: OECD calculations based on OECD Economic Outlook Database (No. 101), June 2017.

(forrás: https://www.oecd.org/korea/Employment-Outlook-Korea-EN.pdf)

\section{Újragondolt humánerőforrás-gazdálkodás}

Az 1997-es ázsiai pénzügyi krízis volt a közvetlen oka annak, hogy a 90-es évek második felétől, mind politikai, mind gazdasági szempontból megindul a rendszer korrekciója, ennek részeként megszületik a koreai munkaügyi szervezet és felértékelődik a pályaorientáció, illetve a felnőttkorban megszerzett tudás beszámítása és felhasználása (skills audit). A ma látható koreai képesség politika e felismerés eredményének a terméke (OECD, 2012), amelyben fokozott figyelem irányul a jelenleg „túlképzett” a középiskolát végzettek $82 \%$-a belép a felsőoktatásba (Economist, 2011)- koreai munkaerő és a munkaadói igények közötti összhang kialakítására valamint a vállalatok és a képzési rendszer közötti kapcsolatrendszer fejlesztésére. A gazdaság meghatározó tevékenységét a szolgáltató szektor adja (59,5\%), miközben a szektor termelékenysége alig nő és szétválik a biztos státuszú foglalkoztatott a részmunkaidős, projekt-alapú vagy kisvállalatnál foglalkoztatott munkaerőtől.

\section{Az oktatási rendszer szerkezete}

Az oktatásirányítás két részre oszlik Koreában is, az Oktatási Minisztérium irányítja a képzési intézményrendszert (ide értve a szakképző közép iskolákat is) és az egész életen át tartó tanulást elősegítő központokat, de a Munkaügyi és Foglalkoztatáspolitikai Minisztérium felelős a szakképzésért és a képzések tartalmáért és e szakmai továbbképzésért. Az általános képzés az óvodával együtt 3+9 év, amelyben különválik az általános iskola alsó és felső tagozata, az középfokú és felsőfokú képzés összesen további 5-7 évet tesz ki. A rendszer tetején a felnőtt szakemberek folyamatos továbbképzése áll.

\section{2. számú táblázat a koreai oktatási rendszer}

\section{diplomások továbbképzése}

\section{egyetem (4 év)} alkalmazott egyetem (2-4 év) (junior college) 


\title{
gimnázium (3 év)
}

\author{
felső általános iskola (3 év) \\ alsó általános iskola (6 év) \\ óvoda (3 év)
}

A felnőtt munkavállalók esetében a KOREATECH - Koreai Képesség Minősítési Hatóság (Korean Skills Quality Authority ${ }^{1}$ ) feladata a gazdasági igényeknek megfelelő szakképzési készségek/ kompetenciák szerinti képzések szervezése. Ezek rövidtávú a gazdasági igényeire azonnal reagáló vállalati képzések átlagosan 12 órában. A képzési igényeket az angolszász országok gyakorlatából ismert képesség tanácsok biztosítják (Skills Councils), amelyekben az adott ágazat (Id. TEÁOR) képviselői ülnek együtt az oktatás és a kormányzat képviselőivel.

\section{Új pályaorientációs politika okai}

Pályaorientációs politikára többnyire akkor van igény egy országba, ha a munkaerőpiacon feszültségek kelteznek, azaz kevés olyan állam van, ahol a lakosság életpálya-építési készségekkel (career management skills, ELGPN 2011) való korai felvértezését főként pedagógiai- oktatáspolitikai feladatnak tekintenék. Koreában a pályaorientáció (career education) 2009-ben került be a tantervbe (Krivet, 2017). A pályaorientációs politikával párhuzamosan fejlődött az állami foglalkoztatási szolgálat rendszere is, amelyet az 1997-98-as ázsiai gazdasági válság nyomán jelentkező tömeges munkanélküliség és újbóli elhelyezkedési, átképzési igények hívtak életre (ILO, 2015). Pályaorientációról és nyugat-európai értelemben vett modern karrier menedzsment igényekről tehát Koreában az 1960-as és 1990-es évek között nem beszélhetünk. A mai modern átmeneti munkaerőpiacok (transitional labour market) helyett ezt az időszakot az intenzív iparosítás és a nagyvállalatok csillapíthatatlan munkaerőigénye jellemezte, munkanélküliség lényegében nem volt. Ebben a vonatkozásban Dél-Korea munkaerőpiacának története közelebb állt a tervgazdálkodást folytató kommunista országok, így Magyarország, jellegzetességeihez, mint Nyugat-Európához. A koreai humánerőforrás-gazdálkodás átalakulásának elmúlt húsz éves története (1997-2017) így kiemelt figyelemre lehet méltó Magyarországon is.

Az 1995-ben elfogadott foglalkoztatási garancia törvény alapozta meg (ILO 2015, Park 2017) azt $a$ modern foglalkoztatás-biztonsági és képzési rendszert, - uniós terminológiával flexicurity rendszer (Európai Közösségek Bizottsága,2007)- amelyben az állam szabályozó szerepét fokozatosan egy munkavállalói képességeket menedzselő funkcióvá alakították át. A foglalkoztatási garancia törvénynek három építőeleme van; a) szakmai kompetenciák fejlesztése, b) foglalkoztatás stabilizációs pillér, c) munkanélküli ellátások. A kortárs koreai gyakorlatban a munkaerőpiaci és képzési szakpolitikai alrendszerek bár adminisztratív irányítási szempontból elvállnak egymástól - két minisztérium van-, de az egyéni életút szintjén szerves egységet alkotnak. A foglalkoztatási garancia törvényt követően fogadták el a munkavállalói szakképzési kompetenciafejlesztési törvényt (1999).

Koreában a vállalatoknak a hetvenes évektől kötelező szerepük van a munkaerő képzésében, továbbképzésében (1967-es majd 1976-os szakképzési törvények), az 1970-es években felvett nemzetközi hitelekből 20 új szakképző központot építettek fel és a vállalatok számára kötelező tették a szakkézben való részvételt. A munkaadókat törvény kötelezte arra, hogy a dolgozók

\footnotetext{
${ }^{1}$ http://www.koreatech.ac.kr
} 
továbbképzésére éves szinten a bértömeg jelentős részét használják fel. A 90-es évek ázsiai gazdasági válsága új alkalmazkodási technikákat követelt meg. Ennek a célnak az érdekében fogadták el 2004ben a szakképzés promócióját támogató, majd 2015-ben a pályaorientációs törvényeket. A jelenlegi fejlesztések eredménye a koreai munka-tanulás duális rendszere (Work-Learning Dual System) (Park et al. 2017:24), amelyben a tanulók egyben munkaszerződéssel rendelkező dolgozók is a tanulmányaik alatt. Ez a rendszert 2014-ben tovább erősítették, nem a német vagy a svájci rendszerek másolásáról, hanem ezeket is integráló, de saját nemzeti fejlesztésről van szó.

A kiinduló probléma Koreában is az volt, mint szerte a világban mindenütt, hogy a szakképzési rendszer sohasem képes a vállalatok számára azonnal használható munkaerőt biztosítani. A koreai válasz a munka és iskola „összefolyatása” volt erre a kihívásra. Tehát vagy maga a vállalat vagy a vállalatok és az állam által múködtetett közös képző központ lényegében munkatevékenységbe ágyazva végzi el a munkaerő felkészítetését és továbbképzését. Más szavakkal kifejezve, a koreai rendszer visszalép a valamikori tanoncképzéshez, ahol a vállalat volt a szakemberképzés, mesterképzés végpontja, de ezt az ipari társadalom tömegigényeire szabva teszi meg.

2. Számú táblázat a koreai munka-tanulás duális rendszere (Park et al. 2017:70)

\begin{tabular}{|c|c|c|c|c|}
\hline kategória & fóbb jellemzők & $\begin{array}{c}\text { megvalósító } \\
\text { szervezet }\end{array}$ & $\begin{array}{c}\text { on-the-job } \\
\text { training (OJT) } \\
\text { (munkába } \\
\text { ágyazott képzés) }\end{array}$ & $\begin{array}{c}\text { off-the-job } \\
\text { training (offJT) } \\
\text { (munka nélküli } \\
\text { tanulás) }\end{array}$ \\
\hline egyedi vállalat & $\begin{array}{c}\text { a cégek saját } \\
\text { maguk képzik a } \\
\text { munkavállalóikat }\end{array}$ & vállalat & vállalat & $\begin{array}{c}\text { vállalat vagy } \\
\text { képző központ }\end{array}$ \\
\hline $\begin{array}{l}\text { közös képző } \\
\text { központ }\end{array}$ & $\begin{array}{c}\text { külső közös } \\
\text { tréning központ } \\
\text { képez a } \\
\text { vállalatoknak } \\
\text { munkába } \\
\text { ágyazott } \\
\text { képzések és } \\
\text { hagyományos } \\
\text { képzések } \\
\text { formájában }\end{array}$ & $\begin{array}{c}\text { vállalatok és a } \\
\text { közös képző } \\
\text { központ }\end{array}$ & vállalat & $\begin{array}{c}\text { közös képző } \\
\text { központ }\end{array}$ \\
\hline
\end{tabular}

A munkanélküliek át és továbbképzését hasonló rugalmassággal oldják meg. A munkanélküliek képzése két részre oszlik az intelligens Egyéni Tanulási Kártyára és a manuális kompetenciákat igénylő tömegképzésekre. Az Egyéni Tanulási Kártyára az egyén tanfolyami kimeneteit is képes nyilvántartani az ott elsajátított képességekkel együtt. A tanulási kártyát az egyén tartja karban egy éve az állam maximum 2 millió wont biztosít, kb. 500 ezer Ft, amelyet az egyén oszt be. A tanulási rendszer össze van kötve az on-line Myjobs² rendszerrel. Amennyiben az egyén 180 napig nem aktív a rendszerben elveszíti a tanulási támogatás felét (Park et al. 2017:120-123).

\footnotetext{
${ }^{2}$ https://www.my.jobs/kor/jobs/
} 


\section{Pályaorientációs rendszer elemei}

A koreai pályaorientációs rendszer a 2000-es évek terméke, ahogyan a koreai munkaügyi szervezet is az (KRIVET 2017). Dél-Korea lényegében másfél évtized alatt épített fel a saját nemzeti rendszerét. Első lépésként 2009-ben a pályaorientáció (career education) bekerült a nemzeti alaptantervbe. 2010-ben az öt éves nemzeti fejlesztési terv részévé vált az iskolai pályaorientáció, azaz a tevékenység stratégiai szintre került. 2011-ben a Koreai Oktatási Minisztériumban Pályaorientációs Főosztályt hoztak létre, amely főosztály a KRIVET: Nemzeti Karrier Fejlesztési Központra és a HRD Korea ${ }^{3}$ szakmai kapacitásaira támaszkodva iskolai pályaorientációs tantervi standardokat és tanulási eredményeket határozott meg. A végrehajtás érdekében a koreai iskolákban pályaorientációs tanárokat képeztek ki és vettek fel. A kiválasztott tanárok 570 órás továbbképzést kaptak a pályaorientáció témakörében, mielőtt új feladatkörükben munkába álltak. 2016-ra az általános és középiskolák 97,5\%-ban volt már pályaorientációs tanár. A tanárok és a pályaorientációs rendszerben feladatokat ellátó szakemberek és felhasználók munkáját a CareerNet ${ }^{4}$ informatikai rendszer támogatja. 2012-2013 között az új modell pilotja következett, majd 2015-ben megszületett az első önálló Pályaorientációs Törvény. A törvény az alábbi fejezetekből áll; a) az pályaorientáció fogalmi meghatározása, az életpálya-építési készségek oktatásának jelenlegi struktúrája Koreában, b) pályaorientáció (career education) az általános iskola egyes szintjein, c) pályaorientáció, karrier tanácsadás a felsőoktatásban, d) a Nemzeti Karrier Központ feladatai, a megvalósítás követése, monitoring és értékelés. A törvény felhatalmazása alapján 2016-2020-ra megszületett a Nemzeti Karrier-fejlesztési (pályaorientációs) Terv (KRIVET, 2017).

\section{Összegzés}

A koreai munka-tanulás duális rendszere (Work-Learning Dual System) olyan modern értelemben vett képesség politika rendszerként értelmezhető, amelyeket az OECD (2017c) vagy az Európai Bizottság ${ }^{5}$ maguk is megoldásként ajánlanak az elmúlt évtizedben. E rendszer részeként a pályaorientációs szakpolitika életút-támogató rendszerként értelmezhető, amelynek egyfelől elő kell segíteni az egyének újabb, felnőttkorban megszerzett képességeinek az integrációját saját pályafutásuk menedzselésébe, másfelől rugalmasabb, területi, ágazati, vállalati és egyéni szintú jobb összehangolását kínálja a munkaerőpiac keresleti és kínálati oldalainak.

\footnotetext{
${ }^{3}$ http://www.hrdkorea.or.kr/ENG

${ }^{4}$ http://www.career.go.kr/cnet/front/main/main.do

${ }^{5}$ https://ec.europa.eu/education/policy/strategic-framework/skills-development en
} 


\section{Irodalom}

Európai Közösségek Bizottsága (2007) A rugalmas biztonság - alapvető fontosságú tényező az EU munkaerőpiacának korszerüsitésében COM/2007/0359 végleges

http://eur-lex.europa.eu/legal-content/HU/TXT/?uri=celex:52007DC0359

Economist (2011) Education in South Korea: Glutted with graduates https://www.economist.com/blogs/banyan/2011/11/education-south-korea

ELGPN (2011) Az Európai Pályaorientációs Szakpolitikai Hálózat Szakszótára http://www.elgpn.eu/elgpndb/search/metadata/view/193

Ilho, Yoo (2008) Korea's Economic Development: Lessons and Suggestions for Developing Countries Korean Social Science Journal, XXXV No. 1(2008): 31- 63 old.

Park, Young-bum et al. (2017) The present and future if vocational competency development training in Korea, HRD Korea, Seoul

Ministry of Education, KRIVET (2017) National Career Development Centre: All about career education in Korea, Seoul

OECD (2017a) Taxing wages 2017, Paris

OECD (2017b) Employment Outlook 2017, Paris

OECD (2017c) Skills Outlook, Paris

OECD (2016a) Economic survey Korea 2016, Paris

OECD (2016b), Viktória Kis and Eunah Park (2012) A Skills beyond School Review of Korea

ILO (2015), Sungpil Yang The Public Employment Service in the Republic of Korea

KRIVET (2017) All about career education in Korea, Ministry of Education/ KRIVET: National Career Development Centre

http://iccdpp2017.org/is-2017-in-korea/about-career-education-in-korea/?ckattempt=1

Schmid, Günther (1998) Transitional labour markets: a New European Employment Strategy, SSG Sozialwissenschaften, USB Köln, Discussion Paper

http://www.ssoar.info/ssoar/bitstream/handle/document/12885/ssoar-1998-schmidtransitional labour markets a new.pdf?sequence $=1$ 